\title{
PROMIČU LI HRVATSKE ČITANKE SOCIJALNI MODEL INVALIDITETA?
}

\author{
ANDREA GAŠPAR ${ }^{1}$, JASNA OSTOJIĆ BAUS ${ }^{2}$, MIRJANA JAKOVČEV ${ }^{3}$ \\ 'Osnovna škola "Milan Amruš", Slavonski Brod \\ ${ }^{2}$ Gradsko društvo Crveni križ grada Zagreba, korespondencija: Jasna Ostojić, jasnaostojic1@gmail.com \\ ${ }^{3}$ Osnovna škola "Milan Amruš", Slavonski Brod
}

Primljeno: 16.1.2017.

Izvorni znanstveni rad

Prihvaćeno: 12.5.2017.

UDK: 37.091.64:364-056.26

Sažetak: U formiranju ranih stavova prema osobama s invaliditetom veliki utjecaj ima škola, školski programi, kao i udžbenici. Republika Hrvatska trenutno prolazi kroz proces transformacije koncepta invaliditeta od medicinskog prema socijalnom modelu. Navedeni koncept nije na svim razinama jednak, stoga je cilj ovog istraživanja bio utvrditi jesu li, i u kojoj mjeri, osobe s invaliditetom u hrvatskim čitankama prikazane kroz suvremeni, socijalni model. U skladu s ciljem istraživanja formirana su sljedeća pitanja:

Kolika je zastupljenost tekstova u kojima se spominju osobe s invaliditetom u hrvatskim čitankama? Koja je vrsta invaliditeta najzastupljenija u tekstovima hrvatskih čitanki? Odgovara li zastupljenost pojedinih vrsti invaliditeta u čitankama stvarnom udjelu osoba s invaliditetom u Hrvatskoj? Jesu li osobe s invaliditetom u tekstovima prikazane u okviru medicinskog ili socijalnog modela? Odgovori na pitanja dobiveni su analizom sadržaja uzorka od šesnaest čitanki hrvatskog jezika za razrednu i predmetnu nastavu za školsku godinu 2016./2017., od ukupno četiri različita nakladnika izabranih metodom slučajnog odabira. Rezultati ukazuju na značajnu podzastupljenost tekstova u kojima su prisutne osobe s invaliditetom u hrvatskim čitankama. U cjelokupnom uzorku od šesnaest čitanki i 1320 analiziranih tekstova prisutno je ukupno 25 tekstova u kojima je radnja vezana uz 34 osobe s invaliditetom. U tekstovima su najzastupljenije osobe s tjelesnim invaliditetom $(29,41 \%)$ i oštećenjima vida (26,47\%), a ova zastupljenost djelomično odgovara stvarnim udjelima invaliditeta u populaciji. Također, osobe s invaliditetom prikazane su pretežno u okviru socijalnog modela (55,88\%), najčešće kroz pozitivnu diskriminaciju $(44,12 \%)$. Ovaj rad može poslužiti kao dobra polazna točka za buduća istraživanja ove tematike kako bi se pratio proces transformacije modela invaliditeta.

Ključne riječi: socijalni model invaliditeta, invaliditet, čitanke, analiza sadržaja

\section{UVOD}

Školski programi, kao i školski udžbenici, postoje kao svojevrsno ogledalo trenutnih društvenih, političkih, i etičkih vrijednosti. Njihova funkcija kao takvih nije samo obrazovati djecu, već i implicitno utjecati na formiranje i internalizaciju određenih stavova $i$ vrijednosti. U Hrvatskom nacionalnom obrazovnom standardu (MZOS, 2006) koji je bio na snazi do 2010. godine, navodilo se kako je "razvoj stavova, mišljenja, motivacije i volje sastavni dio poučavanja i učenja u osnovnoj školi." Već se tada naglašavalo kako je učenike potrebno poučiti društveno prihvatljivim vrijednostima te promišljanju o njima, a među vrijednostima spominjala su se temeljna ljudska i dječja prava te načela poštivanja različitosti. Čitanke su važan izvor informacija za učenike jer u hrvatskim školama predstavljaju jedno od najčešće korištenih nastavnih sred- stava (Baranović, 2006). Sadržaj udžbenika i čitanki mijenja se u skladu s trenutnim društvenim okolnostima. Čitanke i udžbenici utječu na kolektivno razumijevanje invaliditeta (McKinney, 2005), a njihova analiza može otkriti na koji se način učenicima prezentira koncept invaliditeta te koja paradigma prevladava. Proces transformacije od biomedicinske paradigme $u$ biopsihosocijalnu te društveno-političku paradigmu u Hrvatskoj nije jednak na svim razinama. Kekez Koštro i sur. (2012) zaključili su da na razini sustava i organizacije prevladava socijalni model s početnim modelom ljudskih prava, a na razini pojedinca medicinski model, iako je u procesu prelaska na socijalni model.

\section{Transformacija koncepta invaliditeta}

Zadnjih se desetljeća paradigma koncepta invaliditeta promijenila. Invaliditet je u prošlosti gledan 
isključivo kroz biomedicinsku paradigmu, prema medicinskim dijagnostičkim kriterijima koji su definirali pojedinca. Ovaj model definira invaliditet kao fizičko ili intelektualno oštećenje kojim osoba s invaliditetom odstupa od prosjeka, a "normalno" je funkcioniranje osobe onemogućeno. U okviru medicinskog modela invaliditet se može liječiti, a prema osobi s invaliditetom pristupa se kao prema pacijentu. "Model se zapravo temelji na samilosti i uočljivoj bespomoćnosti osoba $\mathrm{s}$ invaliditetom, a promjena i prilagodba kojoj se teži je promjena osobe s invaliditetom" (Petek, 2011). Naglasak je na "rehabilitaciji pojedinca kako bi postao sposoban da se "uklopi' u društvo" (Žiljak, 2006). Društvene prepreke ne očituju se samo u namjernoj segregaciji, nego i u arhitektonskim barijerama, kao i organiziranom društvenom djelovanju koje isključuje ili ograničava sudjelovanje ljudi za koje se smatra da imaju određeni oblik invaliditeta (Wasserman i sur. 2016). Suprotno tome gledištu, razvila se biopsihosocijalna i društveno-politička paradigma koja shvaća invaliditet kao složeno iskustvo koje se definira i oblikuje društvenim i političkim kontekstima unutar kojih se događa. Invaliditet se promatra kroz način na koji osobe svakodnevno žive i ostvaruju vlastita prava prema različitim društvenim i političkim uvjetima (Holland, 2008). Invaliditet je posljedica psihičkih i socijalnih barijera s kojima su osobe s invaliditetom svakodnevno suočene. Riječ je o kompleksnom fenomenu koji nastaje kao rezultat interakcije specifičnih karakteristika individue i karakteristika njena okruženja - nepristupačne fizičke okoline te opresivnih i diskriminatornih socijalnih struktura (Petek, 2011).

\section{Socijalni model invaliditeta}

Kroz 70-te godine prošlog stoljeća na području zaštite psihičkog zdravlja pojavljuje se tzv. "antipsihijatrijski pokret", u sklopu kojeg se medicinski pristup nastoji zamijeniti tzv. socijalnim pristupom ili modelom (Flaker, 1998., prema Urbanc, 2005). Socijalni model ističe da je društvo uzrok što pojedinac s fizičkim ili psihološkim razlikama postaje “invalid”. Drugim riječima, osobe s oštećenjima nisu "invalidi" samo zbog njihovog oštećenja nego i zbog barijera koje postoje u društvu koje ne uzima u obzir njihove potrebe (British Council of Disabled People, prema BRAIN.HE., 2010, prema Mihanović 2011). Socijalni model razlikuje biološ- ko oštećenje od invaliditeta, pri čemu naglašava da je invaliditet kreiran od prepreka iz društva, osobama s određenim biološkim oštećenjima. Dakle, invaliditet je posljedica interakcije između osobe s oštećenjem i društva, a nije posljedica samog oštećenja. Neke verzije socijalnog modela drže naglasak na socijalnim uzrocima, ali inzistiraju na poznavanju karakteristika invaliditeta (Bickenbach, 1993; Altman, 2001). U skladu s promjenama u klasifikaciji transformiraju se i modeli politike prema osobama s invaliditetom. Država pokušava djelovati na promjene u društvu i osigurati jednakost osobama s invaliditetom. Promjena uloga osoba s invaliditetom iz pasivnih primatelja usluga $u$ aktivne zagovaratelje svojih prava i potreba te širenje pokreta za prava osoba $\mathrm{s}$ invaliditetom otvorili su vrata suvremenom modelu ljudskih prava, koji preusmjerava fokus sa zadovoljenja potreba osoba $\mathrm{s}$ invaliditetom na borbu za njihova prava (Kekez Koštro i sur. 2012). Time paradigmu socijalne skrbi preokreće u paradigmu ljudskih prava (Kim, 2010). Više nije riječ samo o dosezanju (pravne) jednakosti, već i o djelovanju usmjerenom k razvijanju potencijala osoba $\mathrm{s}$ invaliditetom u svrhe njihova osnaživanja pa je naglasak na građaninu kao na nositelju ljudskih prava i njegovoj aktivnosti, a ne na invaliditetu (Igrić, 2004). Ideja inkluzije, uključivanja osoba s invaliditetom prema njihovim željama u redovne tokove života u lokalnoj zajednici, teško je ostvariva dijelom i zbog kulturološkog nasljeđa koje projicira negativna uvjerenja prema invaliditetu. Urbanc (2005) govori o invaliditetu kao "kulturološkoj zarazi" koja se, između osta$\log$, ogleda i u negativnom prikazivanju likova u dječjim bajkama koji imaju neki vidljiv tjelesni invaliditet (npr. grbe, osakaćene udove, izobličeno lice), dok se istovremeno likove koji su zdravi i fizički pravilni prikazuje kao inteligentne i dobre. Kulturološke vrijednosti nadasve se prenose i kroz osnovno školovanje, a primarno kroz udžbenike i materijale koji se koriste kao standard i "norma" u određenom društvu. Zato je interes u ovom radu bio prvenstveno analizirati upravo čitanke iz hrvatskog jezika za osnovnu školu.

\section{CILJ I ISTRAŽIVAČKA PITANJA}

Kroz ovo istraživanje evaluirano je jesu li, i $\mathrm{u}$ kojoj mjeri, osobe s invaliditetom u hrvatskim 
čitankama prikazane kroz socijalni model. U tom svjetlu ovim se radom pokušalo istražiti prikazuju li naše osnovnoškolske čitanke, i u kojoj mjeri, djecu ili odrasle osobe s invaliditetom. Invaliditet je definiran na osnovi hrvatskog Registra osoba s invaliditetom (Benjak, 2016) kroz slijedeće kategorije: tjelesni invaliditet; poremećaji pažnje i koncentracije; oštećenja vida; oštećenja sluha; intelektualne teškoće; oštećenja glasovno-govorne komunikacije; psihički poremećaji; višestruke teškoće; oštećenje drugih organa i poremećaji iz autističnog spektra.

Cilj istraživanja je bio otkriti na koji se način prikazuje te osobe, s posebnim interesom za suvremeni socijalni model invaliditeta. Prema tome, istraživačka pitanja bila su slijedeća:

- Kolika je zastupljenost tekstova u kojima se spominju osobe $\mathrm{s}$ invaliditetom $\mathrm{u}$ hrvatskim čitankama?

- Koja je vrsta invaliditeta najzastupljenija u tekstovima hrvatskih čitanki?

- Odgovara li zastupljenost pojedinih vrsti invaliditeta u čitankama stvarnom udjelu osoba s invaliditetom u Hrvatskoj?

- Jesu li osobe s invaliditetom u tekstovima prikazane u okviru medicinskog ili socijalnog modela?

\section{METODA}

U ovom radu koristila se metoda analize sadržaja. Metoda analize sadržaja široko je upotrebljavana upravo u istraživanju školskih udžbenika, a javlja se u različitim kontekstima. Krippendorff (2004) definira analizu sadržaja kao istraživačku tehniku za dobivanje valjanih i provjerljivih zaključaka iz tekstova (ili drugih smislenih sadržaja) u okviru konteksta u kojima se javljaju. Metoda ima dugu povijest $u$ znanstvenim disciplinama $u$ području komunikacija, novinarstva, sociologije, psihologije, ekonomije, a u posljednjih 30-tak godina intenzivno se popularizirala u svim društvenim znanostima (Neuendorf, 2002). Metodom analize sadržaja često su istraživani upravo školski udžbenici, prema različitim temama, poput zastupljenosti koncepta motivacije (Shahmohammadi, 2013), UNICEF-ovih vrijednosti (Fallahi, Nya, 2011), populacijskoj/demografskoj edukaciji
(Yadav, Malik, Meena, 2014), prema rodnoj ravnopravnosti (Mirza, 2004) te prema mnogim drugim temama. Klasična metoda analize sadržaja je kvantitativnog karaktera, što je vidljivo u prvom dijelu ove analize (frekvencije pojavljivanja osoba $\mathrm{s}$ invaliditetom) ali i u drugom dijelu (prikazivanje osoba kroz medicinski ili socijalni model), gdje se varijable unaprijed određuju, a ne formiraju se naknadno iz sadržaja, kao što je to slučaj u kvalitativnoj analizi.

\section{Uzorak}

Populacijski okvir činilo je 28 čitanki hrvatskog jezika za razrednu i predmetnu nastavu koje je odobrilo Ministarstvo znanosti i obrazovanja Republike Hrvatske za školsku godinu 2016./2017., od ukupno četiri različita nakladnika. Iz tog je okvira, metodom slučajnog odabira, izabrano ukupno šesnaest čitanki, za svaki razred po dva različita nakladnika. Jedinicu uzorka je činila jedna čitanka. Cjelokupan prikaz čitanki iz uzorka prikazan je u Tablici 1.

\section{Mjerni instrument}

Za potrebe istraživanja konstruirana je analitička matrica od šest kategorija varijabli, nominalne razine mjerenja. Matrica je konstruirana na način da slijedi stroge kriterije koje predlaže Krippendorff (2004); da su sve kategorije međusobno isključive, te da su kategorije iscrpne (tj. da "pokrivaju" sve mogućnosti odgovora). To se postiglo na način da je u svakoj kategoriji uvedena i opcija "nije moguće utvrditi", za slučajeve kada nije moguće procijeniti jedinicu analize prema zadanom kriteriju. Matrica se sastojala od šest dihotomnih varijabli koje su se kodirale numerički na slijedeći način: odgovor "da" kodiran je kao broj jedan, a odgovor "ne" kodiran je kao nula. Definicije za kodiranje sadržaja prema zadanim varijablama bile su sastavni dio matrice, a preuzimane su iz hrvatskog rječnika (vidi napomene 4, 5, 6 i 7), prema uputama koje predlaže Neuendorf (2002). Prikupljeni podaci obrađeni su na razini relativnih frekvencija. Jedinice prikupljanja podataka bili su tekstovi unutar čitanki kao zasebne sadržajne cjeline, a jedinice analize bile su osobe s invaliditetom u tekstovima u čitankama. Postotak slaganja među analitičarima 
Tablica 1. Prikaz čitanki iz uzorka istraživanja

\begin{tabular}{|c|c|c|c|c|}
\hline Nakladnik & Naziv čitanke & Autori & Godina izdanja & Razred \\
\hline Školska knjiga & Pčelica početnica: 1 . dio & Krmpotić, Ivić & 2010. & Prvi \\
\hline Školska knjiga & Pčelica početnica: 2 . dio & Krmpotić, Ivić & 2009. & Prvi \\
\hline Profil & P kao početnica: 1 . dio & Budinski, Diković, Ivančić, Germadnik & 2015. & Prvi \\
\hline Profil & P kao početnica: 2 . dio & Budinski, Diković, Ivančić, Germadnik & 2015. & Prvi \\
\hline Školska knjiga & Zlatna vrata 2 & Krmpotić, Ivić & 2013. & Drugi \\
\hline Profil & Hrvatski na dlanu 2 & Marjanović,Škribulja,Gabelica, Gredelj & 2015. & Drugi \\
\hline Školska knjiga & Zlatna vrata 3 & Krmpotić, Ivić & 2014. & Treći \\
\hline Alfa & Kuća igrajuća & Zalar, Dvornik, Petruša & 2015. & Treći \\
\hline Školska knjiga & Zlatna vrata 4 & Krmpotić, Ivić & 2013. & Četvrti \\
\hline Profil & Hrvatski na dlanu 4 & Marjanović,Škribulja, Gabelica,Gredelj & 2015. & Četvrti \\
\hline Školska knjiga & Snaga riječi 5 & Šojat & 2014. & Peti \\
\hline Ljevak & Hrvatska čitanka 5 & Bežen, Jambrec & 2014. & Peti \\
\hline Alfa & Zvijezda jutarnja 6 & Babić, Golem & 2015. & Šesti \\
\hline Ljevak & Hrvatska čitanka 6 & Bežen, Jambrec & 2009. & Šesti \\
\hline Školska knjiga & Snaga riječi 7 & Šojat & 2014. & Sedmi \\
\hline Ljevak & Hrvatska čitanka 7 & Bežen, Jambrec & 2014. & Sedmi \\
\hline Školska knjiga & Snaga riječi 8 & Šojat & 2014. & Osmi \\
\hline Ljevak & Hrvatska čitanka 8 & Bežen, Jambrec & 2014. & Osmi \\
\hline
\end{tabular}

nije bio izračunat, ali se vodilo računa o jasnim definicijskim polazištima i uputama za kodiranje sadržaja.

\section{Varijable istraživanja}

U radu su se mjerile sljedeće varijable: pojavljivanje osobe s invaliditetom, vrsta invaliditeta, prikazivanje osobe s invaliditetom kao bolesne, sažalijevanje osobe s invaliditetom, prikaz osobe $s$ invaliditetom nevezano za invaliditet, pozitivna diskriminacija osobe s invaliditetom. U radu se polazilo od pretpostavke da kategorije "sažalijevanje OSI" te "prikazivanje OSI kao bolesne" označavaju medicinski model invaliditeta, dok kategorije "pozitivna diskriminacija OSI" te "prikaz OSI nevezano za invaliditet" označavaju socijalni model invaliditeta. ${ }^{1}$

\section{REZULTATI I RASPRAVA}

\section{Zastupljenost tekstova u kojima se spominju osobe s invaliditetom u hrvatskim čitankama}

Na slici 1. vidljivo je da se broj tekstova $s$ osobama s invaliditetom češće pojavljuje u višim razredima. U šestom je razredu prisutan najveći

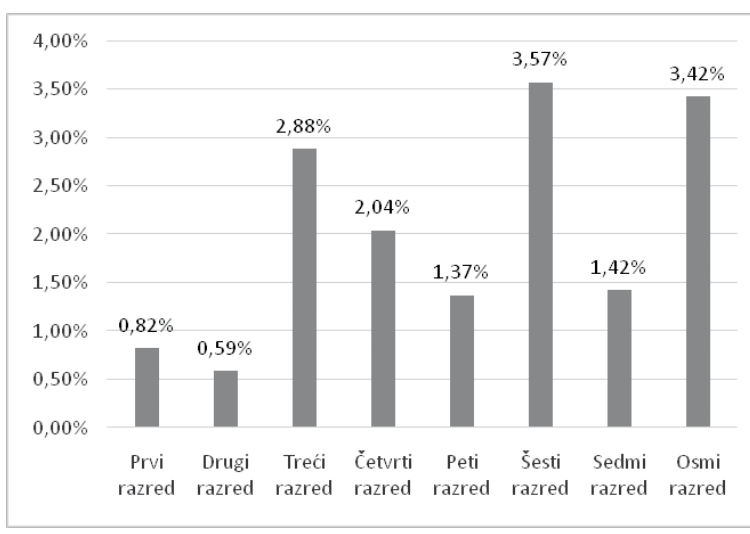

Slika 1. Frekvencije tekstova s osobama s invaliditetom unutar ukupnog broja tekstova po razredima.

broj tekstova s osobama s invaliditetom $(3,57 \%)$, zatim u osmom razredu (3, 42\%), potom slijedi treći $(2,88 \%)$ i četvrti razred $(2,04 \%)$. U ostalim je razredima tekstova s osobama s invaliditetom manje od $2 \%$. U cjelokupnom uzorku od 16 čitanki i 1320 analiziranih tekstova od 1 . do 8 . razreda prisutno je ukupno 25 tekstova u kojima je radnja vezana uz 34 osobe s invaliditetom. Rezultati ukazuju na značajnu podzastupljenost tekstova u kojima su prisutne osobe s invaliditetom u hrvatskim čitankama. Ovi rezultati u skladu su s istraživanji-

1 Spomenute varijable smatrane su valjanim indikatorima za mjerenje koncepata medicinskog i socijalnog modela invaliditeta, temeljeno na pretraženoj literaturi i teorijskim objašnjenjima koncepata. 
ma Batarelo i sur. (2010), Lee (2011), Yip Cheng i Biglar Beigi (2011), te Feng-San Su (2014), koji su također pronašli značajnu podzastupljenost osoba $\mathrm{s}$ invaliditetom u tekstovima čitanki i udžbenika. To ukazuje na vrlo malu prisutnost pojavljivanja teme invaliditeta u čitankama, što je možda dijelom zasluga pokušavanja da se djecu zaštiti od "teških" tema, kakvom se još uvijek često smatra tema invaliditeta.

\section{Zastupljenost pojedinih vrsta invaliditeta $u$ čitankama u odnosu na stvarni udio osoba $s$ invaliditetom u Hrvatskoj}

Na slici 2. prikazano je kako se broj i vrsta osoba s invaliditetom u čitankama razlikuje od stvarne zastupljenosti u populaciji osoba s invaliditetom. U čitankama su najviše zastupljene osobe $\mathrm{s}$ tjelesnim invaliditetom $(29,41 \%)$, zatim s oštećenjima vida (26, 47\%). Zastupljeno je $8,82 \%$ osoba s poremećajem pažnje i koncentracije ${ }^{2}$, intelektualnim teškoćama i psihičkim poremećajima. Slijede oštećenja sluha $(5,88 \%)$ te oštećenja glasovno-govorne komunikacije (4, 40\%). Osobe $\mathrm{s}$ višestrukim teškoćama i poremećajima iz autističnog spektra ne spominju se u čitankama. Ovi rezultati u skladu su s istraživanjima Lee (2011) te Feng-San Su (2014) koji su također pronašli da su najzastupljenije osobe s tjelesnim invaliditetom. Također, Pehrson (2010) je pronašla sličnu zastupljenost i u književnim djelima gdje su $43 \%$ činile osobe s motoričkim poremećajima, a $19 \%$ osobe s oštećenjima vida. Batarelo i sur. (2010) su pronašli da se najviše osoba s invaliditetom spominje u kontekstu tjelesnog invaliditeta i oštećenja vida. Bilo bi potrebno dodatno istražiti koji su razlozi prezastupljenosti tekstova s navedenim vrstama invaliditeta, no možemo pretpostaviti da je tome pridonijela fizička vidljivost teškoće, kao i vidljivost samih osoba u redovnim uvjetima života (u odnosu prema drugim vrstama invaliditeta). Također, veća je mogućnost nastanka spomenutih teškoća redovnim starenjem, zbog čega se djeca češće susreću s tim oblicima teškoća i lakše im ih je predočiti. Stoga, više je fizičkih prilagodbi

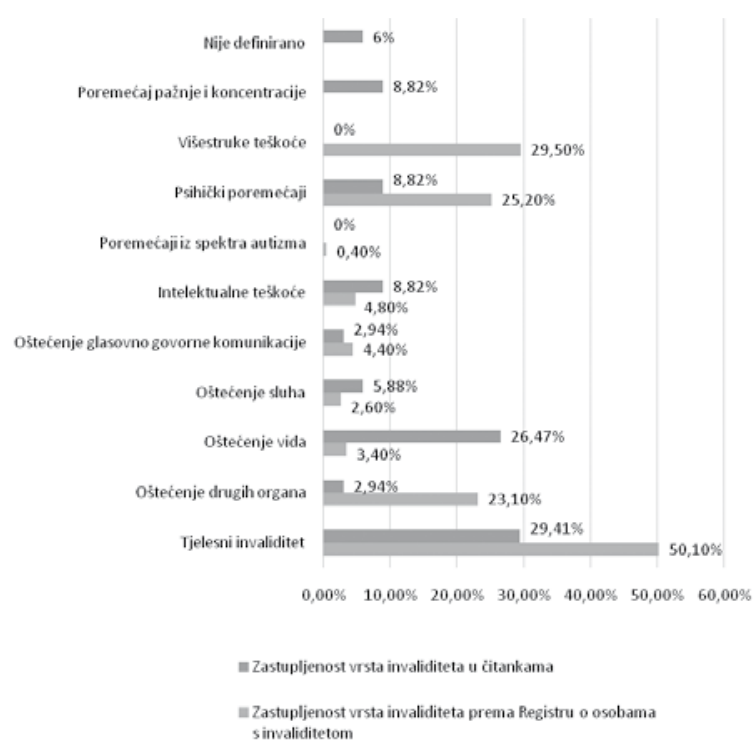

Slika 2. Usporedba zastupljenosti osoba s invaliditetom prema vrstama invaliditeta u čitankama i hrvatskom Registru osoba s invaliditetom.

i oznaka u javnim prostorima za spomenute vrste teškoća, a oni također utječu na vidljivost i svjesnost o njima.

U usporedbi s podacima iz Registra osoba $\mathrm{s}$ invaliditetom (Benjak, 2016) dobivene su tri skupine vrsta invaliditeta prema zastupljenosti u čitankama. U skupini podzastupljenih vrsta su višestruke teškoće $(0 \%)$, poremećaji iz spektra autizma $(0 \%)$, oštećenja drugih organa (2.94\%) te psihički poremećaji (8.82\%). Optimalno zastupljeni su oštećenja glasovno-govorne komunikacije (2.94\%) i tjelesni invaliditet $^{3}(29.41 \%)$. Prezastupljeni su oštećenja vida $(26.47 \%)$, intelektualne teškoće $(8.82 \%)$ te oštećenja sluha (5.88\%). Spomenuti podaci navode na zaključak da nisu sve vrste invaliditeta jednako vidljive u čitankama, te se time djeci ne omogućuje da ravnomjerno upoznaju različitosti unutar pojma invaliditeta. Pogotovo su u tom smislu zakinuta djeca za upoznavanje s poremećajem iz autističnog spektra i višestrukim teškoćama, koje se u cijelom uzorku ne pojavljuju niti u jednom tekstu. Psihički poremećaji su također kategorija koja je u čitankama vrlo slabo zastupljena, a koja je u stvarnoj populaciji visoko zastupljena. U čitankama se iz

2 Nisu dostupni podaci iz hrvatskog Registra osoba s invaliditetom.

3 Radi lakšeg uspoređivanja podataka, tri vrste invaliditeta iz Registra (2016) grupirane su u jednu zajedničku, na način da su kategorije "Oštećenje lokomotornog sustava", "Oštećenje središnjeg živčanog sustava" i “Oštećenje perifernog živčanog sustava” grupirane u zajedničku kategoriju "Tjelesni invaliditet". 
te kategorije pojavilo nekoliko priča vezanih za ovisnosti (droga). S druge strane, zanimljivo je da su oštećenja vida vrlo često spominjani invaliditet u čitankama, a praćen je i bogatim slikovnim sadržajem. Postotak osoba s oštećenjima vida $u$ čitankama daleko premašuje stvaran broj tih osoba u populaciji.

\section{Medicinski ili socijalni model prikaza osoba s invaliditetom}

Na slici 3. vidljivo je kako je većina osoba s invaliditetom $(44,12 \%)$ prikazana kroz pozitivnu diskriminaciju ${ }^{4}$, dok je $11,76 \%$ osoba prikazano nevezano za invaliditet ${ }^{5}$. Prema tome, 55,88\% osoba prikazano je u kontekstu socijalnog modela invaliditeta. Nadalje, 14,71\% osoba prikazano je kao bolesno ${ }^{6}$ i $14,71 \%$ kao sažalijevano ${ }^{7}$. Dakle, ukupno $29,42 \%$ osoba prikazano je kroz medicinski model invaliditeta.

Iako je ovakav način operacionalizacije konstrukata socijalnog i medicinskog modela sveden na samo dva indikatora, on obuhvaća esencijalne značajke oba modela. Stoga možemo donijeti zaključak primjenjiv na osnovnoškolske čitanke iz hrvatskog jezika u Hrvatskoj općenito, da pretežno prikazuju osobe s invaliditetom kao "junake" koji su uspjeli srušiti određene barijere i ostvariti uspjehe unatoč svojim teškoćama $(44,12 \%$ - pozitivno diskriminirani). Iako to možemo interpretirati kao pristupanje invaliditetu kroz socijalni model, to i dalje nije dovoljno, jer prikazuje osobe s invaliditetom na stereotipan, nerealan način te ih predstavlja jedino kroz tu dimenziju (zanemarujući sve ostale osobine i uloge tih osoba). Može se pretpostaviti da je to dijelom posljedica namjere da se invaliditet predstavi na pojednostavljen (djeci razumljiv) i pozitivan način.

Nadalje, samo $11,76 \%$ osoba sa invaliditetom u čitankama je predstavljeno kroz neku drugu osobinu i/ ili ulogu osim postojanja invaliditeta. To su uglavnom slučajevi u kojima je invaliditet bio

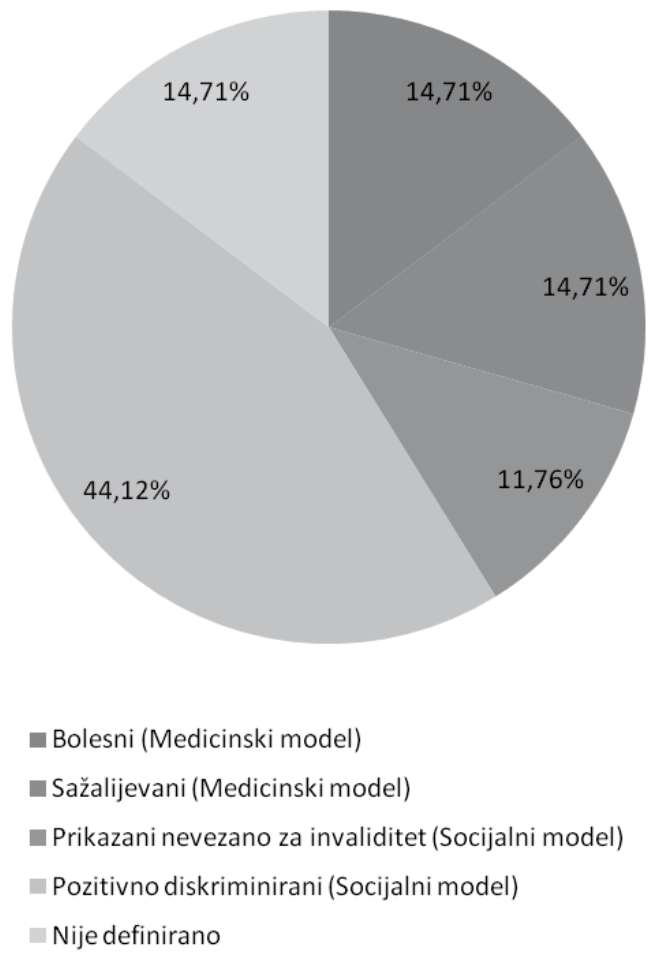

Slika 3. Način prikaza osoba s invaliditetom u tekstovima hrvatskih čitanki

samo usputno spomenut kao dio priče, ali se priča nije gradila na tome, već na nekim drugim značajkama osoba u priči. Takvim se načinom čitatelje usputno upoznaje sa postojanjem invaliditeta, ali im se pritom ne podastiru pojednostavljeni prikazi tih osoba, već se ostavlja prostora za razvijanje osobe neovisno o njegovom/njezinom invaliditetu. Prema mišljenju autorica ovog rada, takav bi način bio više u skladu s shvaćanjem invaliditeta kroz socijalni model. Nadalje, obeshrabruje podatak da se čak $14,71 \%$ osoba sa invaliditetom u čitankama prikazuje kao bolesno, i jednako toliko ih se prikazuje kao osobe koje treba sažalijevati. To nas upućuje na zaključak da su u skoro $30 \%$ slučajeva osobe sa invaliditetom u čitankama prikazivane kroz medicinski model.

4 Razumna prilagodba u smislu Zakona o zabrani diskriminacije (Vlada RH, 2009); osobi s invaliditetom omogućena je određena olakšica radi izjednačavanja mogućnosti s redovnom populacijom, npr. srušena je neka fizička ili socijalna barijera. Ukazuje na socijalni model invaliditeta.

5 Uloga i radnja osobe s invaliditetom u priči nisu povezane s činjenicom da osoba ima invaliditet (kroz tekst u čitanci invaliditet nije istaknut kao dominantna značajka osobe). Ukazuje na socijalni model invaliditeta.

6 Osoba u tekstu prikazana je kao bolesna. Bolest označava poremećaj funkcija organizma, narušenost zdravlja (Hrvatski jezični portal, http:// hjp.znanje.hr/, Anić i sur. 2004), a bolesnik je onaj koji trpi, patnik (Anić i sur. 2004). Ukazuje na medicinski model invaliditeta.

7 Osoba u tekstu je sažalijevana, što znači staviti osobu u podređen položaj, ražalostiti, ožalostiti se (Hrvatski jezični portal, http://hjp.znanje. hr/, Anić i sur. 2004). Ukazuje na medicinski model invaliditeta. 


\section{ZAKLJUС̆AK}

Rezultati su pokazali podzastupljenost tekstova s osobama s invaliditetom u hrvatskim čitankama. Najzastupljenije vrste invaliditeta u čitankama su tjelesni invaliditet te oštećenja vida. Kada se usporedi stvarni udjel populacije s onim zastupljenim u tekstovima čitanki, vidljivo je da su kategorije glasovno-govornih poremećaja komunikacije i tjelesnog invaliditeta optimalno zastupljene. U čitankama su izostavljene osobe s višestrukim teškoćama i autizmom. Možemo zaključiti da prikaz osoba $\mathrm{s}$ invaliditetom $\mathrm{u}$ čitankama ne odgovara stvarnim udjelima invaliditeta u populaciji, na način da su u čitankama najzastupljeniji prikazi najvidljivijih i najjasnijih vrsta invaliditeta (tjelesnog invaliditeta i oštećenja vida, te oštećenja sluha i intelektualne teškoće koja su dvostruko zastupljenije u čitankama nego u populaciji). Kako bismo rano utjecali na stavove i mišljenja prema osobama s invaliditetom, u svrhu stvaranja adekvatnih uvjeta za zaživljavanje socijalnog modela, potrebno je u pričama prikazivati i osobe s ostalim vrstama invaliditeta (primjerice višestruke teškoće i autizam).

Osobe s invaliditetom u čitankama su prikazane i kroz medicinski i kroz socijalni model, iako prevladava socijalni model. Ovom rezultatu najviše pridonosi varijabla "pozitivna diskriminacija" osoba s invaliditetom u čitankama, dok je varijabla "osoba je prikazana nevezano za invaliditet" najmanje zastupljena. No, osobe su prikazane stereotipno, najviše kroz tjelesni invaliditet i oštećenja vida. Slično nalazima Feng-San Su (2014), i ovo je istraživanje pokazalo da se invaliditet većinom prezentira kao osobna, a ne kao društvena pojava. Također, još uvijek je prisutan značajan broj tekstova u čitankama koji osobe s invaliditetom prikazuju kroz medicinski model (kao bolesne i sažalijevane). Osim toga, osobe s invaliditetom bi trebalo prikazivati i kroz njihove ostale karakteristike i/ili uloge, a ne ih samo svoditi na invaliditet. Veća vidljivost osoba s invaliditetom $u$ čitankama doprinijela bi većoj senzibilizaciji i društvenim promjenama u duhu socijalnog modela. Shubert (1989) smatra da način na koji su prikazane osobe s invaliditetom u udžbenicima i čitankama utječe na oblikovanje stavova, mišljenja i ponašanja učenika prema osobama s invaliditetom. Imajući to na umu, svjesni smo važnosti koju čitanke, kao i cjelokupno osnovnoškolsko obrazovanje, imaju u stvaranju temeljnih društvenih vrijednosti. Bognar (2004) navodi da "vladajuće društvene grupe nameću svoj vrijednosni sustav i školama te da se on mijenja kako se mijenjaju te različite grupe na vlasti”. Autorice ovog rada mišljenja su da je potrebno mijenjati vrijednosni sustav i obratnim putem, "odozdo" prema gore, $\mathrm{tj}$. od individualnih i lokalnih razina prema političkim i sustavnim razinama.

Ovim je istraživanjem učinjen određen iskorak $\mathrm{u}$ pristupu istraživanju invaliditeta, te je to prema autoricama ovog rada jedan od najvećih doprinosa tog rada. Po prvi puta se na ovakav način pokušalo analizirati dio obrazovnog sustava kao institucionalni instrument društvenih promjena. Temi invaliditeta nije se pristupalo iz kuta samih osoba sa invaliditetom, već iz sadržaja obaveznog obrazovnog materijala (čitanki) koji se trenutno svakodnevno nudi djeci u čitavoj zemlji. Također, znanstveni se doprinos ovog rada ogleda u mogućnosti generalizacije nalaza na cijelu populaciju osnovnoškolskih čitanki hrvatskog jezika, budući da je uzorak čitanki bio velik i slučajan. Ipak, budući da je ovaj rad obuhvatio širok raspon istraživačkih pitanja, postoje određena ograničenja u njemu. Primjerice, zaključivanje o prevladavajućem modelu invaliditeta u okviru kojeg se prikazuju osobe s invaliditetom u čitankama temeljeno je na relativnom malom broju indikatora. Također, usporedba vrsta invaliditeta u čitankama sa onima u Registru bila je otežana jer i nakon usklađivanja terminologije i vrsta invaliditeta $i$ dalje nisu obuhvaćene sve razvojne teškoće (npr. poremećaji pažnje i koncentracije), te se čini da su Registrom bolje obuhvaćeni podaci o invaliditetu kao posljedici bolesti, nego podaci o razvojnim teškoćama. ${ }^{8}$ Budućim bi istraživanjima trebalo istražiti latentan sadržaj čitanki, kao i dubinski interpretirati dobivene podatke, a to bi se trebalo učiniti kvalitativnom analizom. Također, bilo bi dobro istražiti na koji način učitelji prezentiraju sadržaj tekstova učenicima, jer je učiteljska interpretacija teksta ono što u konačnici oblikuje

8 Registar o osobama s invaliditetom (2016) temelji se na izvorima podataka iz šest različitih sustava, a neke razvojne teškoće se formalno ne registriraju ni u jednom sustavu do polaska u školu, ili čak i dulje. Također, Registar prepoznaje i kategoriju "Prirođene anomalije i kromosomopatije", koje u čitankama nismo mogli prepoznati pa nisu ni analizirane. 
učenikove stavove i vrijednosti. Valjalo bi istražiti i ostale osnovnoškolske udžbenike, pogotovo društvenih predmeta, prema istoj tematici. Konačno, ovaj rad može poslužiti kao dobra polazna točka za buduća istraživanja ove tematike kako bi se pratio proces transformacije modela invaliditeta. 


\section{LITERATURA}

Altman, B. (2001): Disability Definitions, Models, Classification Schemes, and Applications. U: Albredht, G.L., Seelman, K.D., Bury, M. (ur.) Handbook of Disability Studies. (str. 97-122). Thousand Oaks, CA: Sage Publications.

Anić, V., Brozović Rončević, D., Goldstein, I., Goldstein, S., Jojić, Lj., Matasović, R. i Pranjković, I. (2004): Hrvatski enciklopedijski riječnik. Zagreb: Novi Liber.

Baranović, B. (2006): Nacionalni kurikulum za obvezno obrazovanje u Hrvatskoj - različite perspektive. Zagreb: Institut za društvena istraživanja u Zagrebu, Centar za istraživanje i razvoj obrazovanja.

Baranović, B., Doolan, K., Jugović, I. (2010): Jesu li čitanke književnosti za osnovnoškolsko obrazovanje u Hrvatskoj rodno osjetljive? Sociologija i prostor 187, 2, 349-374.

Batarelo, I., Čulig, B., Novak, J., Reškovac, T., Spajić Vrkaš, V. (2010): Demokracija i ljudska prava u osnovnim školama: teorija i praksa. Zagreb: Centar za ljudska prava.

$<\mathrm{http}$ ://ombudsman.hr/dodaci/533_Knjiga\%20prijelom_final.pdf $>$ (pristupljeno: prosinac 2016.)

Benjak, T. (2016): Izvješće o osobama s invaliditetom u Republici Hrvatskoj. Zagreb: Hrvatski zavod za javno zdravstvo.

Bickenbach, J. (1993): Physical Disability and Social Policy. Toronto and London: University of Toronto Press.

Bognar, L. (2004): Analiza tekstova u osnovnoškolskim čitankama. Metodički ogledi : časopis za filozofiju odgoja, 11, 1, 9-27.

Fallahi, V., Nya, M. S. (2011): Content analysis of reading and writing textbooks of the primary school of Iran regard in UNICEF's Decuple Values. Procedia - Social and Behavioral Sciences, 15, 471-474.

Holland, David (2008): The current status of disability activism and NGOs in post-communist Europe: Preliminary findings based on reports from the field. Disability and Society 23, 6, 543-555.

Igrić, Ljiljana (2004): Društveni kontekst, posebne potrebe / invaliditet / teškoće u razvoju i edukacijsko uključivanje. Hrvatska revija za rehabilitacijska istraživanja. 40, 2, 237-250.

Kekez Koštro, A., Urbanc, K., Salaj, I. (2012): Implementacija javnih politika kao operativno upravljanje: analiza transformacije hrvatske politike prema osobama s invaliditetom. Anali Hrvatskog politološkog društva 9, 413- 439.

Kim, S. K. (2010): UN Disability Rights Convention and Implications for Social Work Practice. Australian Social Work $63,1,103-116$.

Krippendorff, Klaus H. (2004): Content Analysis: An Introduction to Its Methodology. New Delhi: SAGE Publications.

Lee, T.-L., (2011): Content Analysis of People with Disabilities in Chinese-Language Elementary School Textbooks. Journal of Textbook Research, 4, 1, 31-54.

McKinney C. (2005): Textbooks for diverse learners. A critical analysis of learning materials used in South African schools. Cape Town: HSRC Press.

Mihanović, V. (2011): Invaliditet u kontekstu socijalnog modela. Hrvatska revija za rehabilitacijska istraživanja, 47, $1,72-86$.

Ministarstvo znanosti, obrazovanja i športa (2006): Hrvatski nacionalni obrazovni standard. Zagreb: Vlada RH, Ministarstvo znanosti, obrazovanja i športa.

Mirza, M. (2004): Gender Analysis of School Curriculum and Text Books. Islamabad: UNESCO.

Neuendorf, Kimberly A. (2002): The Content Analysis Guidebook. London: Sage Publications.

Pehrson, C. (2010): Portrayal of Characters with Disabilities in Newbery Book. Thesis. Boston: Department of Counseling Psychology and Special Education, Brigham Young University. 
Petek, A., (2010): Transformacija politike prema osobama s invaliditetom u Hrvatskoj: analiza ciljeva. Anali Hrvatskog politološkog društva 7, 101-121.

Schubert W.H. (1989): Curriculum: Perspective, paradigm and possibility. New York: Macmillan.

Shahmohammadi (2013): Content Analysis of Elementary Science Text Books Based on the Achievment Motivation Constructs. Procedia - Social and Behavioral Sciences, 84, 426-430.

Su, F.-S. (2014): The Representations of Disabled People in Elementary School Textbooks in Post-War Taiwan. XVII ISA World Congress of Sociology, Facing an Unequal World: Challenges for Global Sociology, July 2014., Yokohama, Japan. $<$ https://isaconf.confex.com/isaconf/wc2014/webprogram/Paper40526.html> (pristupljeno: prosinac 2016.)

Urbanc, K. (2005): Medicinski, socijalni ili neomedicinski pristup skrbi za osobe s invaliditetom. Ljetopis socijalnog rada, 12, 2, 321-333.

Žiljak, Tihomir (2006): Invaliditet je pitanje ljudskih prava: Može li obrazovanje pomoći njihovu ostvarenju? Anali Hrvatskog politološkog društva, 2, 247-259.

Wasserman, D., Asch, A., Blustein, J. and Putnam, D., (2016): Disability: Definitions, Models, Experience. U: Edward N. Zalta (ed.) The Stanford Encyclopedia of Philosophy, Stanford.

$<$ http://plato.stanford.edu/archives/sum2016/entries/disability> (pristupljeno: srpanj 2016.)

Yadav, S., Malik, B., Meena, S. H. (2014): Content Analysis of NCERT Text Book from Population Education Point of View. New Delhi: National Council of Educational Research and Training, Sri Aurobindo Marg.

Yip Cheng, K. K., Biglar Beigi, A. (2011): Addressing students with disabilities in school textbooks. Disabiliy \& Society 26, 2, 239-242.

\section{DO CROATIAN TEXTBOOKS PROMOTE A SOCIAL MODEL OF DISABILITY?}

\footnotetext{
Abstract: School curriculum and textbooks greatly influence the early formation of attitudes towards people with disabilities. Croatia is currently undergoing a transformation from a medical to social model of disability. To assess how this transformation is progressing in schools, the present study examined whether, and to what extent, people with disabilities are presented according to the social model in elementary school textbooks. The following questions were considered: How many texts per textbook in each grade mention people with disability? Which type of disability occurs most often in texts? Is the representation of various types of disability in textbooks consistent with their actual prevalence in the Croatian population? Are textbook portrayals of people with disability aligned with a medical or social model of disability? To address these questions, content analysis was performed on texts randomly sampled from 16 elementary textbooks of the Croatian language used in the 2016-2017 school year. Each publisher was represented to a similar extent in the sample. Of the 1,320 analyzed texts, only 25 mentioned a total of 35 people with disabilities, indicating significant under-representation of people with disabilities in Croatian textbooks. The most common disabilities presented in the sample were physical (29.41\%) and visual (26.47\%), which is to some extent consistent with Croatian statistical data. Most people with disability are portrayed from the perspective of the social model (55.88\%), mainly in the context of positive discrimination (44.12\%). These results may serve as a good starting point for future research on this subject, and they may help monitor disability model transformation in the country.
}

Key words: social model of disability, disability, textbook, content analysis 